\title{
PENGARUH ARUS KAS OPERASI, ARUS KAS INVESTASI, DAN ARUS KAS PENDANAAN TERHADAP RETURN SAHAM PADA PERUSAHAAN MANUFAKTUR YANG TERDAFTAR DI BEI PERIODE 2014-2019
}

\author{
Baru Harahap", Syahril Effendi ${ }^{2}$ \\ Universitas Putera Batam \\ email: baru@puterabatam.ac.id
}

\begin{abstract}
This study aims to determine the effect of cash flows from operating, investing, and financing to stock Return. Data obtained from the income statement, cash flow statement, as well as stock market prices daily on Textile companies listed on the Stock Exchange 2014-2019. The analytical tool used is multiple linear regression, $F$ test and t test. The samples are 15 companies Textile sector during the period 2014-2019. Based on the survey results revealed that a significant difference between cash flows from operating, investing, and financing on stock Returns with sig <0.05. T test results of each independent variable cash flows from operating, investing, and financing an effect on stock Returns (Returns) with sig < 0.05. The conclusion that can be drawn is that the investors who want to invest their shares in the company on the Indonesian Stock Exchange should pay attention to the ratio of a company's cash investment object, because of the results showed that the cash flow effect on stock Returns.
\end{abstract}

Keywords : Operating activities, investing activities, financing activities, stock return

\section{PENDAHULUAN}

Saham merupakan salah satu instrument pasar keuangan yang paling populer. Menerbitkan saham adalah salah satu pilihan perusahaan ketika memutuskan untuk pendanaan perusahaan. Pada sisi yang lain, saham merupakan instrument investasi yang banyak pilihan para investor karena saham mampu memberikan tingkat keuntungan yang menarik (Martalena, 2011:12).

Harga saham merupakan indikator keberhasilan pengelolaan perusahaan dimana kekuatan pasar ditunjukan dengan transaksi perdagangan saham perusahaan di pasar modal. Terjadinya transaksi tersebut didasarkan pada hasil pengamatan para investor terhadap prestasi perusahaan dalam menghasilkan keuntungan. Pada prinsipnya, semakin baik prestasi perusahaan dalam menghasilkan keuntungan akan meningkatkan permintaan saham sehingga harganya akan mengalami peningkatan. Akan tetapi jika prestasi perusahaan semakin buruk maka akan menurunkan harga saham yang bersangkutan. Jadi disini dapat disimpulkan bahwa harga saham merupakan alat bantu pemantau prestasi perusahaan. Selain itu harga pasar saham juga merupakan indeks prestasi perusahaan, yaitu seberapa jauh manajemen telah berhasil mengelola perusahaan.

Return memungkinkan investor untuk membandingkan keuntungan aktual ataupun keuntungan yang diharapkan dan disediakan oleh berbagai investasi pada tingkat pengembalian yang diinginkan. Disisi lain, Return pun memiliki peran yang amat signifikan dalam menentukan nilai dari suatu investasi. Return juga merupakan keuntungan yang dinikmati oleh investor atas tindakan investasi yang dilakukan. Dalam investasi saham, investor akan memilih saham perusahaan yang memberikan tingkat keuntungan tertinggi.

Penelitian Baridwan (1997) dalam Rohman (2005) menunjukkan bahwa pengungkapan informasi arus kas ternyata memberikan nilai tambah bagi para pemakai laporan keuangan. Sedangkan Triyono (1998) dalam Rohman (2005) menguji kandungan informasi arus kas dari aktivitas pendanaan, investasi, operasi dan laba akuntansi dengan harga dan Return saham. 
Hasil penelitian Triyono (1998) menyatakan bahwa dengan modal level, total arus kas tidak mempunyai hubungan yang signifikan dengan harga saham. Sedangkan model Return hipotesis nol mengenai tidak adanya hubungan arus total, maupun ketiga komponennya dengan Return tidak berhasil ditolak yang berarti bahwa tidak terdapat hubungan yang signifikan antara total arus kas, maupun ketiga komponennya dengan Return saham.

Pernyataan-pernyataan dari peneliti seperti Bowen, dkk (1987), Rayburn (1986) dan Barlev dan Livnat (1989) dalam Wahyuni (2002) juga menunjukkan bahwa arus kas operasi dan laba mempunyai nilai tambah laporan keuangan yang diharapkan oleh investor dan berpengaruh terhadap Return saham. Arus kas operasi dan earning dapat meningkatkan hubungan dengan Return saham.

Hal ini dikuatkan dengan penelitian sebelumnya yang tidak konsisten dengan hasil yang diperoleh. Hasil penelitian Wilson (1986), Bernard et.al. (1989), Bahnson et.al. (1996), Baridwan (1997), Triyono (1998) menemukan terdapat kandungan informasi dalam laporan arus kas khususnya arus kas operasi dan laba. Sementara hasil penelitian Clubb (1995) dalam Rohman (2005) menyatakan bahwa kandungan informasi laporan arus kas memberikan dukungan yang lemah bagi investor. Bahkan penelitian Board dan Day (1989) serta Board, dkk (1989) dalam Wahyuni (2002) menyatakan tidak adanya hubungan antara data arus kas dan Return saham.

Arus kas merupakan bagian penting dalam perusahaan, kelangsungan perusahaan akan terhenti tanpa adanya arus kas. karna perusahaan tanpa adanya arus kas, itu berarti sama saja perusahaan tersebut tidak berjalan. Semua kegiatan yang dilakukan suatu perusahaan dicatat pada laporan arus kas tersebut. Arus kas digunakan untuk melihat kinerja perusahaan di bursa dalam rangka membeli saham perusahaan yang bersangkutan, karna dengan demikian para pemakai laporan keuangan dapat menilai dan membandingkan nilai sekarang dari arus kas masa depan dari berbagai perusahaan. Arus Kas merupakan salah satu indikator yang perlu dipertimbangkan oleh investor dalam menanamkan saham nya. Dengan adanya Arus Kas, kita dapat melihat kinerja perusahaan tersebut, apabila semakin meningkat perubahan arus kas perusahaan, maka makin baik pula kinerja perusahaan yang bersangkutan dan akhirnya akan berpengaruh terhadap saham perusahaan tersebut. Laporan Arus kas harus disajikan dengan menilai komponen komponen dari aktifitas operasi, investasi dan pendanaan.

Arus kas perusahaan diklasifikasi menjadi tiga kelompok yaitu arus Kas Operasi, Arus Kas Investasi dan Arus Kas Pendanaan. Arus Kas Operasi yaitu semua aktivitas dengan upaya perusahaan untuk menghasilkan produk, sekaligus semua upaya yang terkait dengan upaya menjual produk tersebut. Arus Kas Investasi adalah semua aktivitas yang terkait dengan pembelian dan penjualan harta perusahaan yang dapat menjadi sumber pendapataan perusahaan. Dan arus kas pendanaan adalah semua yang berkaitan dengan upaya untuk mendukung opersasi perusahaan dengan menyediakan kebutuhan dana dari berbagai sumber beserta konsekuensinya.

Pelaporan keuangan merupakan sistem dan sarana penyampaian informasi oleh manajemen kepada pihak-pihak yang berkepentingan terhadap perusahaan tentang segala kondisi dan kinerja perusahaan terutama dari segi keuangan dan tidak hanya terbatas pada apa yang disampaikan dalam laporan keuangan selama periode tertentu. Pelaporan keuangan merupakan salah satu sumber informasi keuangan perusahaan yang dapat digunakan sebagai dasar untuk membuat beberapa keputusan, seperti penilaian kinerja manajemen, pemberian dividen kepada pemegang saham dan lain sebagainya.

Pemakai laporan keuangan meliputi para investor dan calon investor, kreditor (pemberi pinjaman), pemasok, kreditor usaha lainnya, pelanggan, pemerintah, dan lembaga lainnya, karyawan dan masyarakat, serta para pemegang saham. Informasi yang disajikan dalam laporan keuangan bersifat umum, sehingga tidak sepenuhnya dapat memenuhi kebutuhan informasi setiap pemakai. Berhubung para investor merupakan penanam modal yang berisiko, maka ketentuan laporan keuangan yang memenuhi kebutuhan mereka, juga akan memenuhi sebagian besar kebutuhan pemakai yang lain. Adapun tujuan laporan keuangan disusun untuk menyediakan informasi yang menyangkut posisi keuangan, kinerja, dan perubahan posisi 
keungan suatu perusahaan yang bermanfaat bagi sejumlah besar pemakai dalam pengambilan keputusan ekonomi (Prastowo, 2008: 3-5).

Analisa rasio keuangan merupakan instrumen analisa perusahaan yang ditujukan untuk menunjukkan perubahan dalam kondisi keuangan perusahaan yang bersangkutan. Dengan analisa rasio keuangan ini dapat diketahui kekuatan dan kelemahan perusahaan di bidang keuangan. Analisa rasio keuangan dapat juga dipakai sebagai sistem peringatan awal (early warning system) terhadap kemunduran kondisi keuangan perusahaan yang mengakibatkan tidak akan memberikan kepastian going concern perusahaan khususnya untuk perusahaan yang go public. Perusahaan yang melakukan penjualan kepada masyarakat bertujuan untuk menambah modal kerja perusahaan, perluasan usaha dan diversifikasi produk. Untuk menarik investor, perusahaan harus mampu menunjukkan kinerjanya. Pengukuran kinerja dapat dilakukan menggunakan rasio keuangan. Investor tertarik dengan saham yang memiliki Return positif dan tinggi karena akan meningkatkan kesejahteraan investor. Investor sebelum melakukan investasi pada perusahaan yang terdaftar di Bursa Efek Indonesia melakukan analisis kinerja perusahaan antara lain menggunakan rasio keuangan sehingga kinerja keuangan perusahaan berkaitan dengan Return perusahaan (Husnan, 2003).

Berdasarkan penjabaran diatas maka rumusan masalah adalah Seberapa besar Pengaruh Arus Kas Operasi, Arus Kas Investasi dan Arus Kas Pendanaan Terhadap Return Saham Pada Perusahaan Manufaktur Yang Terdaftar di BEI Periode 2014-2019 baik secara pasrsial maupun secara simultan. Tujuan penelitian adalah Untuk mengetahui Pengaruh Arus Kas Operasi, Arus Kas Investasi dan Arus Kas Pendanaan Terhadap Return Saham Pada Perusahaan Manufaktur Yang Terdaftar di BEI Periode 2014-2019, baik secara pasrsial maupun secara simultan.

\section{TINJAUAN PUSTAKA}

\section{A. Arus Kas Aktivitas Operasi}

Kegiatan operasi meliputi transaksi-transaksi yang berakibat pada kas, yang menjadi penentu rugi-laba misalnya peneriman kas, penjualan jasa dan pembayaran kas kepada pemasok (karyawan) untuk memperoleh kesediaan (tenaga kerja) (Sugiri, dkk, 2011: 23). Arus kas dari aktivitas operasi terutama deviden dari aktivitas penghasil utama pendapatan perusahaan. Oleh karena itu, arus kas tersebut pada umumnya berasal dari transaksi dan pristiwa lain yang mempengaruhi pendapatan laba atau rugi. Beberapa contoh arus kas dari operasi menurut standar akuntansi keuangan di Indonesia (IAI, 2007: 8), adalah sebagai berikut:

1. Penerimaan kas dari penjualan barang atau jasa.

2. Penerimaan kas dari royalti, komisi dan pendapatan lain.

3. Pembayaran kas kepada pemasok barang atau jasa.

4. Pembayaran kas kepada karyawan.

5. Penerimaan dan pembayaran kas oleh perusahaan asuransi sehubungan dengan premi, klaim, anuitas dan asuransi lainnya.

6. Pembayaran kas atau penerimaan kembali pajak penghasilan secara khusus sebagai bagian dari aktivitas pendanaan dan investasi.

7. Penerimaan dan pembayaran kas dari kontrak yang diadakan untuk tujuan transaksi usaha dan perdagangan.

Menurut Bragg (2007: 53-54), berdasarkan prinsip akuntansi yang berlaku umum, perusahaan dapat dengan mudah melaporkan angka pendapatan yang besar, bahkan ketika cadangan kas yang mengalir keluar. Arus kas dari rasio operasi dapat digunakan untuk menentukan sejauh mana arus kas berbeda dari tingkat dilaporkan baik laba usaha atau laba bersih. Setiap perbedaan dalam rasio yang bervariasi secara signifikan dari satu adalah indikasi substansial. Beban non-kas atau penjualan di angka pendapatan yang dilaporkan masalah arus kas mungkin jika rasio substansial kurang dari satu. 
Sedangkan menurut Prastowo (2008: 34), menjelaskan bahwa aktivitas operasi adalah aktivitas penghasil utama pendapatan perusahaan dan aktivitas lain yang bukan merupakan aktivitas investasi dan pendanaan. Aktivitas Operasi yaitu semua aktivitas yang berkaitan dengan upaya perusahaan untuk menghasilkan produk, sekaligus upaya perusahaan untuk menjual produk tersebut yang dikatakan oleh (Rudianto, 2009: 17).

Kedua metode tersebut akan menghasilkan angka yang sama. Namun, metode yang paling sering digunakan dalam praktik pelaporan keuangan adalah metode tidak langsung. Berikut penjelasan dari masing-masing metode adalah sebagai berikut:

1. Metode Langsung

Metode langsung (atau disebut juga metode laporan laba rugi) pada hakikatnya adalah menguji kembali setiap item (komponen) laporan laba rugi dengan tujuan untuk melaporkan berapa besar kas yang diterima atau yang dibayarkan terkait dengan setiap komponen dari laporan laba rugi tersebut. Keunggulan metode ini adalah bahwa metode ini melaporkan sumber dan penerimaan kas dalam laporan arus kas. Sedangkan kelemahannya adalah bahwa data yang dibutuhkan seringkali tidak mudah didapat dan biaya pengumpulan umumnya mahal.

2. Metode Tidak Langsung

Metode tidak langsung (atau disebut juga metode rekonsiliasi) dimulai dengan angka laba atau rugi bersih sebagaimana yang dilaporkan dalam laporan laba rugi dan menyesuaikan besarnya laba atau rugi bersih (yang telah diukur atas akrual) dengan item-item yang tidak mempengaruhi arus kas. Keunggulan utama dari metode tidak langsung adalah bahwa metode ini memusatkan pada perbedaan antara laba bersih dan arus kas dari aktivitas operasi. Dalam hal ini, metode tersebut mununjukkan hubungan antara laporan laba rugi, neraca, dan laporan arus kas. Karena datanya dapat tersedia dengan segera, maka metode tidak langsung pada umumnya lebih mudah dibanding metode langsung.

Oleh karna itu, dapat disimpulkan bahwa rumus arus kas operasi menurut Trisnawati, (2013:87) adalah sebagai berikut:

$$
\mathrm{AKO}=\frac{\mathrm{AKO}_{\mathrm{t}}-\mathrm{AKO}_{\mathrm{t}-1} \mathrm{x}}{\mathrm{AKO} \mathrm{t}_{\mathrm{t}-1}} 100 \% \quad \text { Rumus 1. Rumus Arus Kas Operasi }
$$

Keterangan:

$\mathrm{AKO}=$ Arus Kas Operasi

$\mathrm{AKO}_{\mathrm{t}}=$ Arus Kas Operasi i pada periode $\mathrm{t}$

$\mathrm{AKO}_{\mathrm{t}-1}=$ Arus Kas Operasi i pada periode $\mathrm{t}-1$

\section{B. Arus Kas Aktivitas Investasi}

Kegiatan investasi meliputi kegiatan membeli aktiva tetap untuk fasilitas produksi, menjualnya kembali kalau sudah tak terpakai dan kegiatan memberi pinjaman uang serta penerimaan dari hasil tagihan atas pinjaman tersebut (Sugiri, 2011: 23). Pengungkapan terpisah arus kas dari aktivitas investasi perlu dilakukan sebab arus kas tersebut mencerminkan penerimaan dan pengeluaran kas sehubungan dengan sumber daya yang bertujuan untuk menghasilkan pendapatan dan arus kas masa depan.

Beberapa contoh arus kas yang berasal dari aktivitas investasi menurut standar akuntansi keuangan di Indonesia (IAI, 2007: 9), adalah sebagai berikut:

1. Pembayaran uang untuk membeli aktiva tetap, aktiva tak berwujud, dan aktiva jangka panjang lain, termasuk pengembangan yang dikapitalisasikan dan aktiva tetap yang dibangun sendiri.

2. Penerimaan kas dari penjualan tanah, bangunan dan peralatan, aktiva tak berwujud, dan aktiva jangka panjang lain.

3. Perolehan saham atau instrument keuangan perusahaan lain.

4. Uang muka pinjaman yang diberikan kepada pihak lain setara pelunasannya. 
5. Pembayaran sehubungan dengan future contracts, forward contracts (kontak selanjutnya), option contracts, dan swap contracts kecuali apabila kontrak tersebut dilakukan dengan tujuan dealing or trading (perdagangan), atau apabila pembayaran tersebut diklasifikasikan sebagai aktivitas pendanaan.

Aktivitas Investasi adalah berbagai aktivitas yang terkait dengan pembelian dan penjualan harta perusahaanyang dapat menjadi sumber pendapatan perusahaan (Rudianto, 2009: 18). Seperti yang telah disebut awal, yang termasuk sebagai aktivitas investasi adalah membeli atau menjual tanah, bangunan, dan peralatan (Hery, 2011: 247).

Pelaporan arus kas dari aktivitas investasi tidak di pengaruhi oleh metode langsung ataupun metode tidak langsung. Jika arus kas masuk dari aktivitas investasi lebih besar dibanding dengan arus kas keluarnya, maka arus kas bersih yang dihasilkan oleh aktivitas investasi akan dilaporkan. Sebaliknya, jika arus kas masuk dari aktivitas investasi lebih kecil dibanding dengan arus kas keluarnya, maka arus kas bersih yang digunakan dalam aktivitas investasi dilaporkan. Oleh karena itu, dapat disimpulkan bahwa rumus arus kas investasi menurut Trisnawati (2013: 87) adalah sebagai berikut:

$$
\mathrm{AKI}=\mathrm{AKI}_{\mathrm{t}}-\mathrm{AKI}_{\mathrm{t}-1} \mathrm{x} 100 \% \quad \text { Rumus 2. Rumus Arus Kas Investasi }
$$

Keterangan:

AKI $=$ Arus Kas Investasi

$\mathrm{AKI}_{\mathrm{t}} \quad=$ Arus Kas Investasi i pada periode $\mathrm{t}$

$\mathrm{AKI}_{\mathrm{t}-1}=$ Arus Kas Investasi i pada periode $\mathrm{t}-1$

\section{Arus Kas Aktifitas Pendanaan}

Kegiatan pendanaan meliputi kegiatan dengan pemilik dan kreditor yang berpengaruh pada kas, seperti penyetoran modal dan pengambilan prive (pada perusahaan perorangan) atau pembagian dividen tunai (pada perusahaan perseroan), dan penarikan bank serta pelunasannya (Sugiri, 2011: 23).

Menurut standar akuntansi keuangan di Indonesia (IAI, 2007: 10) aktivitas pendanaan adalah aktivitas yang mengakibatkan perubahan dalam jumlah serta komposisi modal dan pinjaman perusahaan. Arus kas yang timbul dari aktivitas pendanaan perlu dilakukan pengungkapan terpisah karena berguna untuk memprediksi klaim terhadap arus kas masa depan oleh para pemasok modal perusahaan. Beberapa contoh arus kas yang berasal dari aktivitas pendanaan adalah sebagai berikut:

1. Penerimaan kas dari emisi saham atau instrumen modal lainnya.

2. Pembayaran kas kepada para pemegang saham untuk menarik atau menembus saham perusahaan.

3. Penerimaan kas dari emisi obligasi, pinjaman, wesel, hipotek, dan pinjaman lainnya.

4. Pelunasan pinjaman.

5. Pembayaran kas oleh penyewa untuk mengurangi saldo kewajiban yang berkaitan dengan sewa pembiayaan.

Menurut Prastowo, (2008: 35), menjelaskan bahwa aktivitas pendanaan adalah aktivitas yang mengakibatkan perubahan dalam jumlah dan komposisi kewajiban (utang) jangka panjang dan modal (ekuitas) perusahaan. Aktivitas pendanaan adalah semua aktivitas yang berkaitan dengan upaya untuk mendukung operasi perusahaan dengan menyediakan kebutuhan dana dari berbagai sumber beserta konsekuensinya (Rudianto, 2009: 18).

Aktivitas pendanaan meliputi transaksi yang di mana kas diperoleh atau dibayarkan kembali ke pemilik dana (investor) dan kreditor. Sebagai contoh, kas bersih yang diterima dari 
penerbitan saham (sekuritas modal) atau obligasi (sekuritas utang), pembayaran untuk membeli kembali saham biasa (sebagai treasury stock), atau untuk menebus kembali utang obligasi, dan pembayaran dividen tunai. Jadi, yang termasuk aktivitas pendanaan adalah meliputi transaksi yang berkaitan dengan utang jangka panjang maupun ekuitas (modal) perusahaan. Ekuitas adalah kepemilikan atau kepentingan residu dalam aktiva entitas, yang masih tersisa setelah dikurangi dengan kewajibannya.

Pelaporan arus kas dari aktivitas pendanaan tidak dipengaruhi oleh metode langsung ataupun tidak langsung. Jika arus kas masuk dari aktivitas pendanaan lebih besar disbanding dengan arus kas keluarnya, maka arus kas bersih yang dihasilkan oleh aktivitas pendanaan akan dilaporkan. Sebaliknya, jika arus kas masuk dari aktivitas pendanaan lebih kecil dibandingkan arus kas keluarnya, maka arus kas bersih yang digunakan dalam aktivitas pendanaan dilaporkan (Hery, 2011: 249). Oleh karena itu, dapat disimpulkan bahwa rumus arus kas pendanaan menurut Trisnawati (2013:87) adalah sebagai berikut:

$$
\mathrm{AKP}=\underset{\mathrm{AKP}}{\mathrm{AKP}_{\mathrm{t}-1}-\mathrm{AKP}_{\mathrm{t}-1} \times 100 \% \text { Rumus 3. Rumus Arus Kas Pendanaan }}
$$

Keterangan:

$\mathrm{AKP}=$ Arus Kas Pendanaan

$\mathrm{AKP}_{\mathrm{t}} \quad=$ Arus Kas Pendanaan i pada periode $\mathrm{t}$

$\mathrm{AKP}_{\mathrm{t}-1}=$ Arus Kas Pendanaan i pada periode $\mathrm{t}-1$

\section{Return Saham}

Alasan utama orang melakukan investasi adalah untuk mendapatkan keuntungan (dalam konteks manajemen investasi tingkat keuntungan investasi disebut sebagai Return). Return adalah hasil yang diperoleh dari investasi pada umumnya melakukan investasi adalah untuk Return (tingkat pengembalian) sebagai imbalan atas dana yang telah ditanamkan serta kesediaannya menanggung resiko yang ada dalam investasi tersebut.

Investor menuntut adanya tingkat Return yang di harapkan sebagai kompensasi atas biaya kesempatan (opportunity cost) dan resiko daya beli akibat adanya pengaruh inflasi. Dalam hal ini Return yang diharapkan (expected Return) dan Return yang terjadi (realized Return). Return yang di harapkan merupakan tingkat Return yang diantisipasi investor di masa yang akan datang. Sedangkan Return yang terjadi atau Return realized merupakan tingkat Return yang telah diperoleh investor di masa lalu. Ketika investor menginvestasikan dananya dia akan mensyaratkan tingkat Return tertentu, dan jika periode investasi telah berlalu, investor tersebut akan di hadapkan pada tingkat Return realized yang di peroleh investor dari investasi. Sehingga dalam berinvestasi, di samping memperhatikan tingkat Return, investor harus selalu mempertimbangkan tingkat risiko dari satu investasi (Pamadanu, 2008: 5).

Komponen Return terdiri dari dua jenis yaitu Current Income (pendapatan lancar) dan Capital Gain (keuntungan selisih harga). Current Income merupakan keuntungan yang diperoleh melalui pembayaran yang bersifat periode seperti pembayaran bunga deposito, bunga obligasi, dividen, dan sebagainya. Disebut sebagai pendapatan lancar, maksudnya adalah keuntungan yang diterima biasanya dalam bentuk kas, atau setara kas, sehingga dapat digunakan secara cepat, seperti bunga atau jasa giro dan dividen tunai. Dan yang setara kas adalah saham bonus atau dividen saham yaitu dividen yang dibayarkan dalam bentuk saham dan dapat diganti menjadi uang kas.

Komponen kedua dari Return adalah Capital Gain (keuntungan modal), yaitu selisih harga investasi sekarang relatif dengan harga periode yang lalu. Secara teori ekonomi, harga pasar suatu saham akan terbentuk melalui proses penawaran dan permintaan yang 
mencerminkan kekuatan pasar. Capital Gain (keuntungan modal) sangat tergantung dari harga pasar instrument investasi, yang berarti bahwa instrumen investasi harus diperdagangkan di pasar. Dengan adanya perdagangan maka akan timbul perubahan nilai suatu instrument investasi yang memberikan capital gain (keuntungan modal).

Sedangkan menurut Trisnawati (2013: 87), Return saham adalah pengembalian hasil atas surat berharga atau investasi dimana biasanya dinyatakan dalam bentuk suatu tingkat persentase serta suatu variabel yang muncul dari perubahan harga saham sebagai akibat dari reaksi pasar karena adanya penyampaian informasi keuangan suatu entitas kedalam pasar modal. Dalam penelitian ini, Return saham diukur menggunakan capital gain (keuntungan modal) merupakan selisih harga investasi sekarang relatif dengan periode lalu dan dapat disimpulkan bahwa rumus Return saham adalah sebagai berikut:

$$
\mathrm{R}_{\mathrm{i}, \mathrm{t}}=\mathrm{P}_{\mathrm{i}, \mathrm{t}}-\mathrm{P}_{\mathrm{i}(\mathrm{t}-1)} \times 100 \% \text { Rumus 4. Return Saham }
$$

Keterangan:

$\mathrm{R}_{\mathrm{i}, \mathrm{t}} \quad=$ Tingkat keuntungan saham i pada periode $\mathrm{t}$

$\mathrm{P}_{\mathrm{i}(\mathrm{t})} \quad=$ Harga Saham i pada periode $\mathrm{t}$

$\mathrm{P}_{\mathrm{i}(\mathrm{t}-\mathrm{l})} \quad=$ Harga Saham i pada periode $\mathrm{t}-1$

Berdasarkan kajian teori di atas, kerangka berpikir dalam penelitian ini yang berjudul Pengaruh Arus Kas Operasi, Arus Kas Investasi dan Arus Kas Pendanaan Terhadap Return Saham Pada Perusahaan Manufaktur Yang Terdaftar di BEI Periode 2014-2019. Dengan adanya Gaya Kepemimpinan dan motivasi ini, diharapkan ikut mendorong peningkatan Return Saham. Sebagai gambaran menyusun penelitian ini maka diperlukan adanya sebuah kerangka pemikiran terperinci, agar pemecahan masalah ini dapat terarah. Secara sistematik kerangka pemikiran dapat dilihat pada gambar berikut ini:

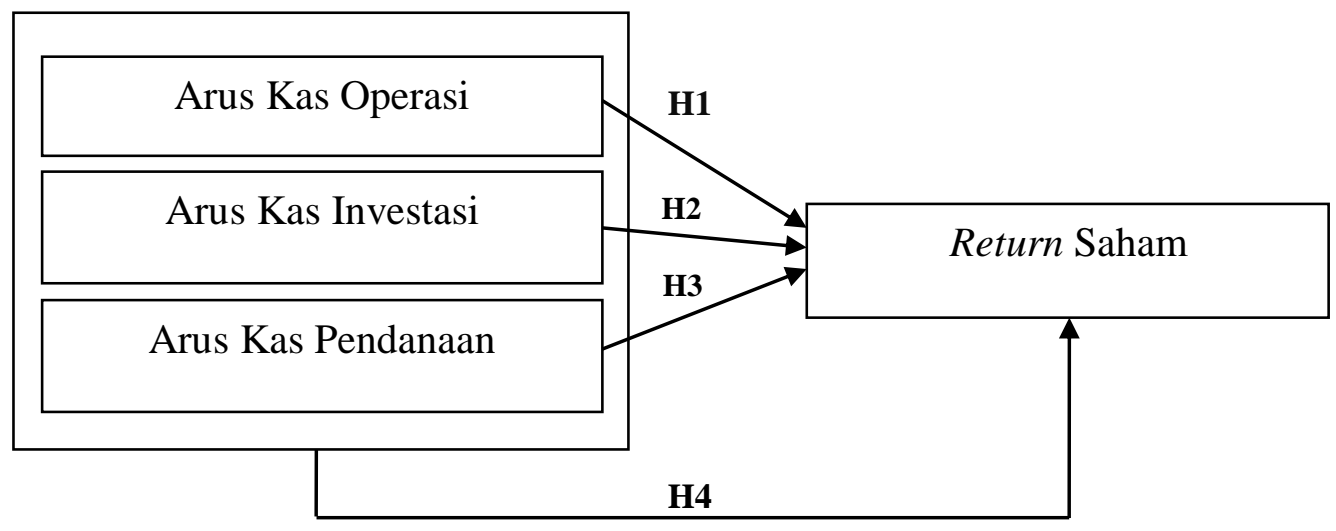

Gambar 1. Kerangka berfikir penelitian

Dari kerangka berfikir maka Hipotesisnya adalah bahwa Arus Kas Operasi, Arus Kas Investasi dan Arus Kas Pendanaan Terhadap Return Saham pada Perusahaan Manufaktur Yang Terdaftar di BEI Periode 2014-2019 baik secara Parsial maupun secara Simultan.

\section{METODE}

Efferin (2012:48) mengemukakan bahwa desain penelitian (research design), adalah merupakan framework dari suatu penelitian ilmiah. Desain penelitian yang baik akan menjadi 
menentukkan keberhasilan serta kualitas dari suatu penelitian ilmiah. Dengan menyusun suatu desain penelitian, peneliti pada dasarnya membuat arahan tentang berbagai hal yang harus dilakukan dalam upaya untuk melakukan suatu penelitian. Di dalam penelitian kuantitatif ini digunakan dua jenis variabel, yaitu variabel independennya (bebas) adalah Arus Kas Operasi $\left(\mathrm{X}_{1}\right)$, Arus Kas Investasi $\left(\mathrm{X}_{2}\right)$ dan Arus Kas Pendanaan $\left(\mathrm{X}_{3}\right)$ dan variabel dependennya (terikat) adalah Return Saham (Y).

Untuk memperjelas konsep dan operasionalisasi dari variabel yang diteliti baik variabel independen maupun variabel dependen, maka peneliti menyajikan tabel operasional variabel sebagai berikut:

Tabel 1. Operasional Variabel

\begin{tabular}{|c|c|c|c|}
\hline Variabel & Konsep Variabel & Indikator & Skala \\
\hline $\begin{array}{l}\text { Arus Kas } \\
\text { Aktivitas } \\
\text { Operasi } \\
\quad\left(\mathbf{X}_{1}\right)\end{array}$ & $\begin{array}{l}\text { Arus Kas Aktivitas } \\
\text { Operasi yaitu arus } \\
\text { kas dari transaksi } \\
\text { yang mempengaruhi } \\
\text { laba bersih. }\end{array}$ & $\begin{array}{l}\text { Arus Kas Operasi }(\text { AKO })= \\
\frac{\text { AKO } t-\text { AKO } t-1 \times 100 \%}{\text { AKO } t-1}\end{array}$ & Rasio \\
\hline $\begin{array}{l}\text { Arus Kas } \\
\text { Aktivitas } \\
\text { Investasi } \\
\quad\left(\mathbf{X}_{2}\right)\end{array}$ & $\begin{array}{l}\text { Arus Kas Aktivitas } \\
\text { Investasi yaitu arus } \\
\text { kas dari transaksi } \\
\text { yang mempengaruhi } \\
\text { investasi dari aktiva } \\
\text { lancar. }\end{array}$ & $\begin{array}{l}\text { Arus Kas Investasi }(\mathrm{AKI})= \\
\frac{\text { AKI } t-\text { AKI } t-1 \times 100 \%}{\text { AKI } t-1}\end{array}$ & Rasio \\
\hline $\begin{array}{l}\text { Arus Kas } \\
\text { Aktifitas } \\
\text { Pendanaan } \\
\quad\left(\mathbf{X}_{3}\right)\end{array}$ & $\begin{array}{l}\text { Arus Kas Aktifitas } \\
\text { Pendanaan yaitu arus } \\
\text { kas dari transaksi } \\
\text { yang mempengaruhi } \\
\text { ekuitas dan hutang } \\
\text { perusahaan. }\end{array}$ & $\begin{array}{l}\text { Arus Kas Pendanaan (AKP) }= \\
\frac{\text { AKP } t-\text { AKP } t-1 \quad \times 100 \%}{\text { AKP } t-1}\end{array}$ & Rasio \\
\hline $\begin{array}{c}\text { Return Saham } \\
\text { (Y) }\end{array}$ & $\begin{array}{l}\text { Return saham adalah } \\
\text { keuntungan yang } \\
\text { dinikmati investor } \\
\text { atas investasi saham } \\
\text { yang dilakukannya. }\end{array}$ & $\begin{array}{c}\mathrm{Ri}, \mathrm{t}= \\
\frac{\mathrm{Pi}, \mathrm{t}-\mathrm{Pi}(\mathrm{t}-1) \times 100 \%}{\mathrm{Pi}(\mathrm{t}-1)}\end{array}$ & Rasio \\
\hline
\end{tabular}

Populasi adalah wilayah generalisasi yang terdiri dari objek atau subjek yang mempunyai kuantitas dan karakteristik tertentu yang ditetapkan oleh peneliti untuk dipelajari yang kemudian ditarik kesimpulannya (Hikmat, 2011: 60). Populasi yang dimaksud adalah populasi jumlah perusahaan Manufaktur yang terdaftar di Bursa Efek Indonesia periode 2014-2019 sebanyak 19 perusahaan.

\section{HASIL DAN PEMBAHASAN}

\section{A. Hasil Pengujian Hipotesis}

Pengujian hipotesis dalam penelitian ini dilakukan dengan menggunakan uji statistik t, uji statistik F 


\section{a. Hasil Uji T}

Uji Statistik t digunakan untuk mengetahui ada atau tidaknya pengaruh masing-masing variabel independen secara parsial terhadap variabel dependen yang diuji pada tingkat signifikansi 0,05. Hasil uji t dalam penelitian ini ditunjukkan dalam tabel 2 dibawah ini.

Tabel 2. Hasil Uji T

Coefficients $^{\mathrm{a}}$

\begin{tabular}{|c|c|c|c|c|c|c|}
\hline \multirow[t]{2}{*}{ Mode } & & \multicolumn{2}{|c|}{$\begin{array}{c}\text { Unstandardized } \\
\text { Coefficients } \\
\end{array}$} & \multirow{2}{*}{$\begin{array}{c}\begin{array}{c}\text { Standardized } \\
\text { Coefficients }\end{array} \\
\text { Beta }\end{array}$} & \multirow[t]{2}{*}{$\mathbf{t}$} & \multirow[t]{2}{*}{ Sig. } \\
\hline & & B & Std. Error & & & \\
\hline \multirow{4}{*}{1} & (Constant) & 4.246 & .662 & & 6.409 & .000 \\
\hline & $\mathrm{AKO}$ & .209 & .050 & .378 & 4.196 & .000 \\
\hline & AKI & .203 & .067 & .320 & 3.004 & .003 \\
\hline & AKP & .111 & .053 & .205 & 2.104 & .038 \\
\hline
\end{tabular}

a. Dependent Variable: RETURN_SAHAM

\section{1) Hipotesis Penelitian Pertama}

Dari tabel 2 menunjukkan bahwa Arus Kas Operasi (AKO) mempunyai $t_{\text {hitung }}$ sebesar 4.196 dengan probabilitas signifikansi adalah 0.000 dan nilai beta yang dihasilkan adalah positif sebesar 0.378. Jika membandingkan antara nilai $\mathrm{t}_{\text {tabel }}$ dengan menggunakan $\mathrm{t}_{(\alpha / 2),(\mathrm{n}-2)}=\mathrm{t}_{(0,05 / 2),(90-2)}$ adalah 1.66235. Hal tersebut menunjukkan bahwa $t_{\text {hitung }}<t_{\text {tabel }}$ dan sig $>\alpha$. Sehingga dapat disimpulkan bahwa $\mathrm{Ho}_{1}$ ditolak dan $\mathrm{H} a_{1}$ diterima yang menyatakan bahwa "Arus Kas Operasi (AKO) berpengaruh positif dan signifikan terhadap Return Saham" diterima.

\section{2) Hipotesis Penelitian Kedua}

Variabel Arus Kas Investasi (AKI) memiliki thitung sebesar 3.004 dengan probabilitas signifikansi adalah 0,003 dan nilai beta yang dihasilkan positif sebesar -0.320. Jika membandingkan antara nilai $\mathrm{t}_{\text {tabel }}$ dengan menggunakan $\mathrm{t}_{(\alpha / 2),(\mathrm{n}-2)}=\mathrm{t}_{(0,05 / 2),(90-2)}$ adalah 1.66235. Hal tersebut menunjukkan bahwa $t_{\text {hitung }}<t_{\text {tabel }}$ dan sig $>\alpha$. Sehingga dapat disimpulkan bahwa $\mathrm{Ho}_{2}$ ditolak dan $\mathrm{Ha}_{2}$ diterima yang menyatakan bahwa "Arus Kas Investasi (AKI) berpengaruh positif dan signifikan terhadap Return Saham" diterima.

\section{3) Hipotesis Penelitian Ketiga}

Variabel Arus Kas Pendanaan (AKP) memiliki $t_{\text {hitung }}$ sebesar 2.104 dengan probabilitas signifikansi sebesar 0,038 dan nilai beta yang dihasilkan positif sebesar -0,205. Jika membandingkan antara nilai $\mathrm{t}_{\text {tabel }}$ dengan menggunakan $\mathrm{t}_{(\alpha / 2),(\mathrm{n}-2)}=\mathrm{t}_{(0,05 / 2),(90-2)}$ adalah 1.66235 . Hal tersebut menunjukkan bahwa $t_{\text {hitung }}<\mathrm{t}_{\text {tabel }}$ dan sig $>\alpha$. Sehingga dapat disimpulkan bahwa $\mathrm{Ho}_{3}$ ditolak dan $\mathrm{Ha}_{3}$ diterima yang menyatakan bahwa "Arus Kas Pendanaan (AKP) berpengaruh positif dan signifikan terhadap Return Saham" diterima.

\section{b. Hasil Uji F}

Uji statistik $F$ digunakan untuk mengetahui apakah semua variabel bebas yang dimasukkan dalam model mempunyai pengaruh secara simultan terhadap variabel terikat. Berikut ini hasil uji statistik F dapat ditunjukan pada tabel 3. 
Tabel 3. Hasil Uji F

ANOVA $^{\mathrm{a}}$

\begin{tabular}{|ll|r|r|r|r|r|}
\hline \multicolumn{1}{|c|}{ Model } & Sum of Squares & \multicolumn{1}{c|}{ Df } & Mean Square & F & \multicolumn{1}{c|}{ Sig. } \\
\hline \multirow{3}{*}{1} & Regression & 932.760 & 3 & 310.920 & $\mathbf{5 0 . 8 5 9}$ & $\mathbf{. 0 0 0}^{\mathbf{b}}$ \\
Residual & 525.747 & 86 & 6.113 & & \\
& Total & 1458.508 & 89 & & & \\
\hline
\end{tabular}

a. Dependent Variable: RETURN_SAHAM

b. Predictors: (Constant), AKP, AKI, AKO

Tabel 3 diatas menunjukkan hasil uji ANOVA atau uji statistik $F$ dengan nilai $F_{\text {hitung }}$ sebesar 50.859 dengan tingkat signifikansi sebesar $0.000^{\mathrm{b}}$. Nilai $\mathrm{F}_{\text {tabel }}$ dapat dicari pada tabel $\mathrm{F}$ dengan ketentuan $F_{\text {tabel }}=F_{(\alpha, k, d f)}$ dan dimana $\alpha=0,05$, $k=3$, df(90-3-1)=86 adalah 2.71. Sehingga $\mathrm{F}_{\text {hitung }} \leq \mathrm{F}_{\text {tabel }}$ serta tingkat signifikansi tersebut lebih besar dari 0,05 dapat disimpulkan bahwa Ho ditolak dan Ha diterima yang menyatakan bahwa variabel Arus Kas Operasi (AKO), Arus Kas Investasi (AKI) dan Arus Kas Pendanaan (AKP) berpengaruh secara simultan dan signifikan terhadap Return Saham.

\section{SIMPULAN}

Berdasarkan hasil analisis data dan pembahasan mengenai perusahaan Manufaktur yang terdaftar di Bursa Efek Indonesia periode 2014-2019 yang telah diuraikan sebelumnya dengan tingkat keyakinan $95 \%$ dapat disimpulkan sebagai berikut:

1. Berdasarkan pengujian hipotesis pertama ditemukan bahwa variabel arus kas operasi mempunyai pengaruh yang signifikan terhadap return saham.

2. Pengujian hipotesis kedua ini berhasil membuktikan adanya pengaruh yang signifikan arus kas investasi terhadap return saham.

3. Pengujian hipotesis ketiga ini berhasil membuktikan adanya pengaruh yang signifikan arus kas pendanaan terhadap return saham.

4. Hasil penelitian ini membuktikan bahwa arus kas operasi, arus kas investasi, dan arus kas pendanaan secara simultan berpengaruh signifikan terhadap return saham.

\section{SARAN}

Adapun rekomendasi yang dapat disarankan penulis untuk penelitian selanjutnya adalah:

1. Para investor yang ingin menanamkan sahamnya pada perusahaan di Bursa Efek Indonesia sebaiknya memperhatikan rasio kas dari perusahaan objek investasinya, karena dari hasil penelitian diperoleh bahwa arus kas berpengaruh terhadap return saham.

2. Untuk melengkapi hasil penelitian, maka sebaiknya dilakukan penelitian serupa dengan menambah sampel dan obyek penelitian yang lebih banyak agar memperoleh kesimpulan yang lebih lengkap dan dapat dipertanggungjawabkan.

3. Bagi penelitian selanjutnya, disarankan agar penelitian ini diuji dengan menambah jumlah sampel yang diteliti dan menambah variabel bebas yang baru (baik sebagai moderating ataupun intervening), seperti resiko sistematik dan EPS. Sangat disarankan untuk menggunakan data dari periode yang berbeda, sehingga di dapat informasi yang dapat mendukung atau memperbaiki penelitian ini.

\section{DAFTAR PUSTAKA}

Bragg, M. S. 2007. Business Ration and Formulas Secoud Edition. America: Simultancously in Canada.

Debbianita dan Elyzabet I. Marpaung, S. M. 2009. Pengaruh Laba Per Saham, Total Arus Kas dan Pendapatan Nilai Perusahaan. Laporan Penelitian .

Dwi Prastowo D., M. A., et al. 2008. Analisis Laporan Keuangan konsep dan aplikasi edisis ke2. Yogyakarta: Sekolah Tinggi Ilmu Manajemen YKPN. 
Efferin, S.. 2012. Metode Penelitian Untuk Akuntansi. Malang: Bayumedia.

Ely Suhayati, et al. 2009. Akuntansi Keuangan. Yogyakarta: Graha Ilmu dan Universitas Komputer Indonesia.

Fahmi, I. 2012. Pengantar Pasar Modal. Bandung: ALFABETA, CV.

Harahap, S. S. 2011. Analisis Kritis atas Laporan Keuangan. Jakarta: PT RajaGrafindo Persada. Hery. 2012. Analisis Laporan Keuangan. Jakarta: PT Bumi Askara.

Hikmat, Mahi M. 2011. Metode Penelitian: Dalam Perspektif Ilmu Komunikasi dan Sastra. Cetakan Pertama. Yogyakarta: Graha Ilmu.

Ikatan Akuntan Indonesia. 2007. Standar Akuntansi Keuangan. Jakarta: Salemba Empat.

Manurung, P. D. 2012. Teori Keuangan Perusahaan. Jakarta: PT Adler Manurung Press.

Martalena, et al. 2011. Pengantar Pasar Modal. Yogyakarta: Penerbit ANDI.

Rudianto. 2009. Pengantar Akuntansi. Jakarta: Penerbit Erlangga.

Sugiri, S., et al. 2011. Akuntansi Pengantar 1. Yogyakarta: Unit Penerbit dan Percetakan AMP YKPN.

Sudarsono, J., et al. 2002. Pengantar Ekonomi Perusahaan. Jakarta: PT Prenhalindo.. 